UDC 338.436.33:351.823.1(571.150)

LBC 65.32.(2Рос-4Алт)

\title{
ECONOMIC ANALYSIS OF THE EFFECTIVENESS OF EXISTING TOOLS OF STATE SUPPORT FOR AGRO-INDUSTRIAL COMPLEX OF THE REGION ${ }^{1}$
}

\author{
Yuriy A. Bugay \\ Altai State Agricultural University, Barnaul, Russian Federation
}

\begin{abstract}
The work is devoted to the evaluation of the effectiveness of existing tools of state support for the development of the agro-industrial complex of the region (the case of the Altai Region). The purpose of the study is to develop a method for determining the appropriateness and effectiveness of the existing tools of state support.

The author's understanding of the essence and structure of tools of state support for agricultural production is presented in the work. On the basis of empirical data, an analysis of the application of these instruments, directions and measures of state support to agriculture is carried out with the use of the data of the Altai Region as one of the leading agrarian-oriented territories of Russia. It is established that the most significant and effective tool of state support for the agro-industrial complex of the region is "providing unrelated support to agricultural producers in the field of crop production".

The author reveals the features of granting subsidies per 1 hectare of agricultural crops in the region, taking into account the specifics of agricultural production, due to different climatic conditions. The analysis of the practice of subsidizing the Altai Region on the basis of indicators of the hydrothermal coefficient makes it possible to conclude that the state agrarian policy at the level of the region under study is effective, because its measures help to level the conditions for profitable behavior of the agrarian business for commodity producers operating in different natural and climatic conditions.

Based on the analysis, a conclusion is made about the effectiveness of state support in the region, but at the same time it is noted that in order to further improve the mechanism for implementing the agrarian policy of the Altai Region, it is necessary to establish a basic price for the main types of agricultural products as an indicative planning tool, and not only direct, but also other types of financing of the agro-industrial complex.

Key words: agro-industrial complex, agrarian policy, state regulation of agriculture, tools of regional state support, economic efficiency of state support.
\end{abstract}

УДК 338.436.33:351.823.1(571.150)

ББК 65.32.(2Рос-4Алт)

\section{ЭКОНОМИЧЕСКИЙ АНАЛИЗ ЭФФЕКТИВНОСТИ СУЩЕСТВУЮЩИХ ИНСТРУМЕНТОВ ГОСУДАРСТВЕННОЙ ПОДДЕРЖКИ АГРОПРОМЫШЛЕННОГО КОМПЛЕКСА РЕГИОНА ${ }^{1}$}

\author{
Юрий Александрович Бугай \\ Алтайский государственный аграрный университет, г. Барнаул, Российская Федерация
}

\begin{abstract}
Аннотация. Работа посвящена вопросам оценки эффективности существующих инструментов государственной поддержки развития агропромышленного комплекса региона (на примере Алтайского края). Целью исследования является разработка методики определения целесообразности и эффективности существующего инструментария государственной поддержки.

В работе представлено авторское понимание сущности и структуры инструментов государственной поддержки сельскохозяйственного производства. На основе эмпирических данных проведен анализ применения данных инструментов, направлений и мероприятий государственной поддержки сельского хозяйства на примере Алтайского края как одной из ведущих аграрно ориентированных территорий России. Установлено, что наиболее значимым и эффективным инструментом государственной поддержки АПК региона
\end{abstract}


является «оказание несвязанной поддержки сельскохозяйственным товаропроизводителям в области растениеводства».

Автором выявлены особенности предоставления субсидии на 1 га посевов сельскохозяйственных культур в регионе с учетом специфики ведения сельскохозяйственного производства, обусловленного разными природно-климатическими условиями. Анализ практики субсидирования территорий Алтайского края на основе показателей гидротермического коэффициента позволил сделать вывод о том, что государственная аграрная политика на уровне исследуемого региона является эффективной в силу того, что ее меры помогают выровнять условия рентабельного поведения аграрного бизнеса для товаропроизводителей, функционирующих в разных природно-климатических условиях.

На основе проведенного анализа делается вывод об эффективности государственной поддержки в регионе, однако вместе с тем отмечается, что для дальнейшего совершенствования механизма осуществления аграрной политики Алтайского края необходимо установление базовой цены на основные виды сельскохозяйственной продукции как инструмента индикативного планирования, а также не только прямое, но и другие виды финансирования агропромышленного комплекса.

Ключевые слова: агропромышленный комплекс, аграрная политика, государственное регулирование сельского хозяйства, инструменты региональной государственной поддержки, экономическая эффективность государственной поддержки.

Государственное регулирование агропромышленного комплекса является важной составляющей системы государственного регулирования экономики в целом. Как показал анализ основных экономических школ, характеризующих степень влияния государства на общественную экономику, любой экономической системе исторически свойственно государственное вмешательство (рис. 1.) [1, с. 176].

Абсолютное саморегулирование экономики в современных реалиях, на наш взгляд, не представляется возможным, так как в условиях глобализации оно приводит к серьез- ным деформациям и диспропорциям территориального социально-экономического развития. Государство, используя актуальные инструменты экономического прогнозирования и регулирования, купирует негативное воздействие политических, природных и иных факторов, препятствующих работе добросовестных экономических агентов в режиме совершенной конкуренции свободного рынка.

Целью представленного исследования является разработка методики определения целесообразности и эффективности применения инструментов государственной поддержки добросовестных субъектов рыночных от-

\begin{tabular}{|c|c|}
\hline $\begin{array}{l}\text { 1. Политика жестких протек- } \\
\text { ционных мер и ограничений } \\
\text { (XVI-XVIII в в.) }\end{array}$ & $\begin{array}{l}\text { Развитие экономики возможно лишь с помощью мер активно- } \\
\text { го государственного вмешательства (меркантилизм) }\end{array}$ \\
\hline $\begin{array}{l}\text { 2. Политика экономического } \\
\text { либерализма (XVIII в.) }\end{array}$ & $\begin{array}{l}\text { Предпочтение отдается капитализму на основе принципа не- } \\
\text { вмешательства государства в экономику (классическая школа) }\end{array}$ \\
\hline $\begin{array}{l}\text { 3. Политика макроэкономи- } \\
\text { ческого регулирования } \\
\text { (XIX-XX вВ.) }\end{array}$ & $\begin{array}{l}\text { Регулирование макроэкономических показателей спроса через } \\
\text { систему бюджетно-финансовой и денежно-кредитной полити- } \\
\text { ки. Развитие государственного сектора (кейнсианство, не- } \\
\text { оклассическая школа) }\end{array}$ \\
\hline $\begin{array}{l}\text { 4. Политика социального го- } \\
\text { сударства (вторая половина } \\
\text { ХХ в. 50-70-е гг.) }\end{array}$ & $\begin{array}{l}\text { Регулирование не только экономических, но и социальных } \\
\text { процессов }\end{array}$ \\
\hline $\begin{array}{l}\text { 5. Политика государственно- } \\
\text { го регулирования рыночного } \\
\text { хозяйства (70-е гг. и по н. в.) }\end{array}$ & $\begin{array}{l}\text { Государство устанавливает правила игры, способствующие } \\
\text { максимально эффективному использованию ресурсов, обеспе- } \\
\text { чивает национальную экономическую безопасность и гаранти- } \\
\text { рует соблюдение интересов рыночных субъектов граждан }\end{array}$ \\
\hline
\end{tabular}

Рис. 1. Исторические этапы государственного присутствия в экономике

Примечание. Составлено автором. 


\section{СОЦИАЛЬНО-ЭКОНОМИЧЕСКОЕ РАЗВИТИЕ РЕГИОНОВ}

ношений в региональном агропромышленном комплексе. Задачи исследования:

- дать понятие и структурировать инструменты государственной поддержки сельскохозяйственного производства;

- проанализировать их применение на примере Алтайского края как одной из ведущих аграрно ориентированных территорий России;

- предложить методику экономической оценки эффективности государственной поддержки АПК.

Рыночный механизм не рассматривается нами как полностью идеальная форма экономических отношений, не требующая какого-либо влияния со стороны государственных институтов. Поэтому государство использует обширный арсенал средств административного и правового, прямого и косвенного экономического регулирования. Методологические принципы и методические подходы к концепции регулирования агропромышленного производства основаны на сочетании саморегулирования рынка и активного воздействия государственных органов.

Основой агропромышленного комплекса является сельскохозяйственное производство. Именно в этой сфере находятся такие средства производства как плодородные земельные ресурсы - природно-экономическая основа планетарной жизни. По оценкам экспертов ООН в области народонаселения, к 2050 г. численность населения земли может достигнуть 9-10 млрд человек. В результате к середине XXI в. во всем мире от 1,6 до 5,5 млрд чел. будут проживать в странах, где не выполняется норматив минимальной обеспеченности обрабатываемыми сельскохозяйственными землями на душу населения. По оценкам этих экспертов, чтобы не превратить человеческую цивилизацию в бойню за пропитание, в перспективе необходимо увеличить производство продуктов питания на 75 \% [4, с. 36].

Роль современного государства, на наш взгляд, в сфере обеспечения безопасных условий функционирования национальной экономики, прежде всего продовольственной безопасности, в перспективе будет только возрастать. Так, например, Указ Президента РФ, которым были введены ограничительные меры по ввозу в нашу страну отдельных ви- дов сельскохозяйственной продукции, сырья и продовольствия в ответ на внешнее санкционное давление, полностью укладывается в логику современной концепции государственного регулирования рыночного хозяйства.

Государство для реализации целей своей экономической политики использует различные формы и методы, которые образуют инструментарий государственного регулирования экономики, среди которых важное место занимают различные формы государственной поддержки сельскохозяйственного производства.

Начиная с реализации Приоритетного национального проекта «Развитие АПК» (20062007 гг.) агропромышленный комплекс новой России получил первоначальный импульс для рыночного развития, которое в настоящее время поддерживается реализацией Государственной программы развития сельского хозяйства и регулирования рынков сельскохозяйственной продукции, сырья и продовольствия на 2008-2012 и 2013-2020 годы.

Благодаря системным мерам государственной поддержки сельского хозяйства были созданы, на наш взгляд, благоприятные условия для привлечения в отрасль стратегических и портфельных инвесторов, обеспечения внутренних потребностей в сельскохозяйственной продукции и восстановления экспортного потенциала. При этом потенциал самого сельского хозяйства России как конкретно способного вида экономической деятельности на глобальных сельскохозяйственных рынках далеко не исчерпан.

Государственная поддержка сельскохозяйственного производства региона основывается на инструментах и принципах государственной аграрной политики Российской Федерации, которая в первую очередь определена целями и задачами Доктрины продовольственной безопасности Российской Федерации, утвержденной Указом Президента Российской Федерации от 30.01.2010 № 120, и реализуется в тесной увязке с «Государственной программой развития сельского хозяйства и регулирования рынков сельскохозяйственной продукции, сырья и продовольствия» на 20132020 годы. В условиях санкций отдельных государств в отношении России и политики импортозамещения региональная поддержка 
Ю.А. Бугай. Экономический анализ эффективности инструментов государственной поддержки

сельскохозяйственного производства направлена на обеспечение максимального вклада региона в обеспечение продовольственной безопасности страны и развитие территорий сельских поселений.

Анализ инструментов государственной поддержки сельскохозяйственного производства показал, что они реализовывались в 2016 г. через три государственные программы (ГП «Развитие сельского хозяйства Алтайского края» на 2013-2020 гг., ГП «Развитие мелиорации земель Алтайского края сельскохозяйственного назначения» на 2014-2020 гг., ГП «Устойчивое развитие сельских территорий Алтайского края» на 2012-2020 гг.) и шесть ведомственных целевых программ (ВЦП «Развитие производства и переработки льна в Алтайском крае» на 2016-2018 гг., ВЦП «Развитие мясного скотоводства в Алтайском крае» на 2016-2018 гг., ВЦП «Развитие в Алтайском крае семейных животноводческих ферм на базе крестьянских (фермерских) хозяйств» на 2016 2018 гг., ВЦП «Поддержка начинающих фермеров в Алтайском крае» на 2016-2018 гг, ВЦП «Развитие сельскохозяйственной потребительской кооперации в Алтайском крае» на 2016-2018 гг., ВЦП «Предотвращение заноса в Алтайский край и распространения на его территории африканской чумы свиней» на 20162018 гг.) [3, с. 3-4].
Общий объем государственной поддержки сельского хозяйства и развития сельских территорий региона за период реализации национального проекта «Развитие АПК» и государственных программ составил более 52,5 млрд руб., в том числе за счет средств краевого бюджета 14,5 млрд руб. [5, с. 64-65].

Динамика финансирования сельского хозяйства и сельских территорий Алтайского края представлена на рисунке 2.

Основные направления и инструменты государственной поддержки, реализуемые в 2016 г. в рамках государственных и ведомственных целевых программ на территории Алтайского края в области растениеводства как наиболее значимой отрасли в удельном весе сельскохозяйственного производства региона, обобщены и представлены на рисунке 3.

Общий объем государственной поддержки сельскохозяйственных товаропроизводителей растениеводческой направленности в рамках государственной программы «Развитие сельского хозяйства Алтайского края» на 2013-2020 гг. и подпрограммы «Развитие подотрасли растениеводства» в 2016 г. составил 2 104,07 млн руб., в том числе за счет регионального бюджета 206,18 млн руб. [3, с. 14].

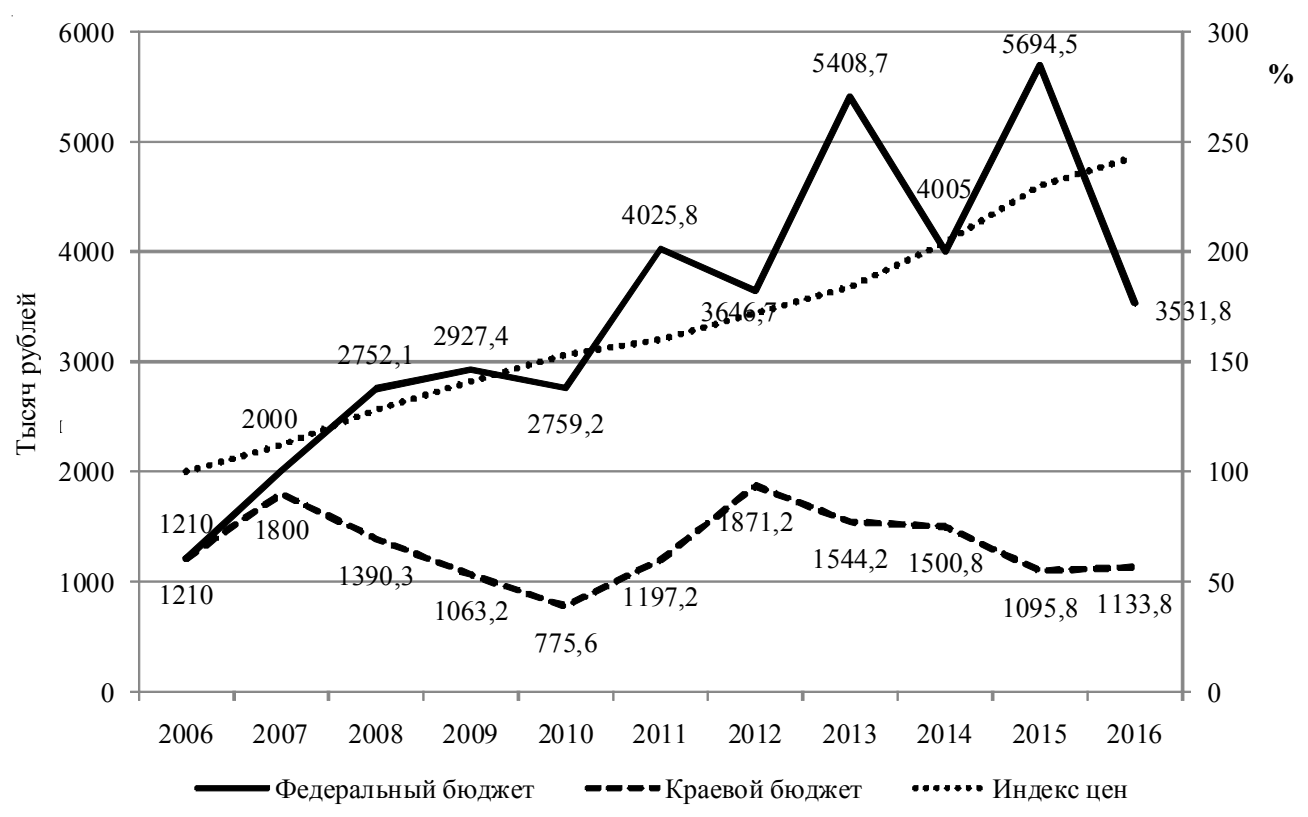

Рис. 2. Динамика финансирования сельского хозяйства и сельских территорий Алтайского края, млн руб.

Примечание. Составлено автором по: [3]. 


\section{ГП «Развитие сельского хозяйства Алтайского края» на 2013-2020 гг.}

\section{Направления (мероприятия)}

Поддержка сельскохозяйственных товаропроизводителей в области растениеводства; поддержка сельскохозяйственных товаропроизводителей в области развития производства семенного картофеля и овощей открытого грунта; поддержка кредитования подотрасли растениеводства; поддержка страхования в подотрасли растениеводства; поддержка развития элитного семеноводства;

поддержка организаций, осуществляющих закладку и уход за многолетними плодовыми и ягодными насаждениями;

поддержка развития производства овощей в защищенном грунте

\begin{tabular}{|c|c|c|c|c|}
\hline & \multicolumn{3}{|c|}{ Инструменты поддержки } & \\
\hline $\begin{array}{c}\text { Погектарные } \\
\text { субсидии } \\
\text { производителям с/x } \\
\text { продукции }\end{array}$ & $\begin{array}{c}\text { Субсидирование } \\
\text { процентной ставки } \\
\text { по кредитам }\end{array}$ & \multicolumn{2}{|c|}{$\begin{array}{c}\text { Субсидии на } \\
\text { поддержку с/х } \\
\text { страхования }\end{array}$} & $\begin{array}{c}\text { Субсидии на } \\
\text { приобретение } \\
\text { элитных семян }\end{array}$ \\
\hline $\begin{array}{l}\text { Субсидии на закладку } \\
\text { многолетних плодовых } \\
\text { и ягодных насаждений }\end{array}$ & \multicolumn{2}{|c|}{$\begin{array}{c}\text { Субсидирование части } \\
\text { затрат на потребленные при } \\
\text { выращивании овощей } \\
\text { энергоносители }\end{array}$} & \multicolumn{2}{|c|}{$\begin{array}{c}\text { Субсидии на реконструкцию } \\
\text { тепличных комплексов, в том числе } \\
\text { котельных, производственных } \\
\text { и складских помещений }\end{array}$} \\
\hline
\end{tabular}

ВЦП «Развитие производства и переработки льна в Алтайском крае» на 2016-2018 гг.

\section{Направления (мероприятия)}

Повышение конкурентоспособности производства и переработки льна в Алтайском крае Увеличение объемов выпуска отечественной льняной продукции

\begin{tabular}{|c|c|c|}
\hline & Инструменты поддержки & ержки \\
\hline $\begin{array}{c}\text { Субсидирование части } \\
\text { затрат производителям, } \\
\text { реализующим лен на } \\
\text { внутреннем рынке }\end{array}$ & $\begin{array}{c}\text { Субсидии на } \\
\text { производство } \\
\text { льна }\end{array}$ & $\begin{array}{c}\text { Субсидии на приобретение техники, } \\
\text { используемой при выращивании льна }\end{array}$ \\
\hline
\end{tabular}

Рис. 3. Мероприятия и инструменты государственной поддержки

Примечание. Составлено автором.

Структура государственной поддержки развития растениеводческой отрасли региона представлена на рисунке 4.

Анализ структуры господдержки показал, что значительную долю бюджетных средств распределяют, используя такой инструмент, как субсидии, направленные на оказание несвязанной поддержки сельскохозяйственным товаропроизводителям, и субсидирование процентной ставки по кредитам. Общая доля данной поддержки составила 90 \% финансовых ресурсов программы (см. рис. 5).

Стоит отметить, что финансирование такого направления, как развитие производства овощей в защищенном грунте, осуществляется исключительно за счет средств краевого бюджета.

Использование основного инструмента государственной поддержки АПК региона «Оказание несвязанной поддержки сельскохозяйственным товаропроизводителям в области растениеводства» регламентируется Постановлением Правительства Алтайского края от 09.02.2017 № 34 «Об утверждении порядка предоставления из краевого бюджета субсидий на оказание несвязанной поддержки в области растениеводства». 
Ю.А. Бугай. Экономический анализ эффективности инструментов государственной поддержки

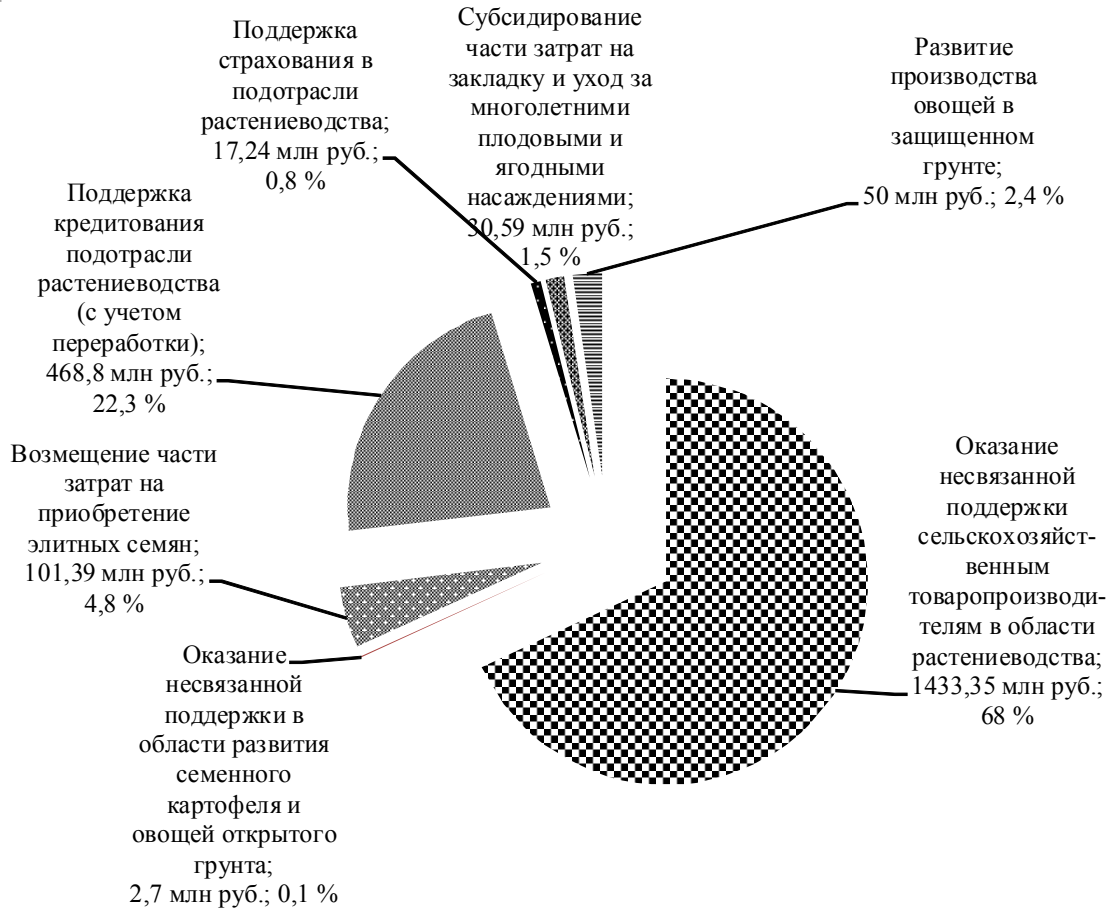

Рис. 4. Структура государственной поддержки сельскохозяйственных производителей отрасли растениеводства в 2016 г.

\section{Примечание. Составлено автором.}

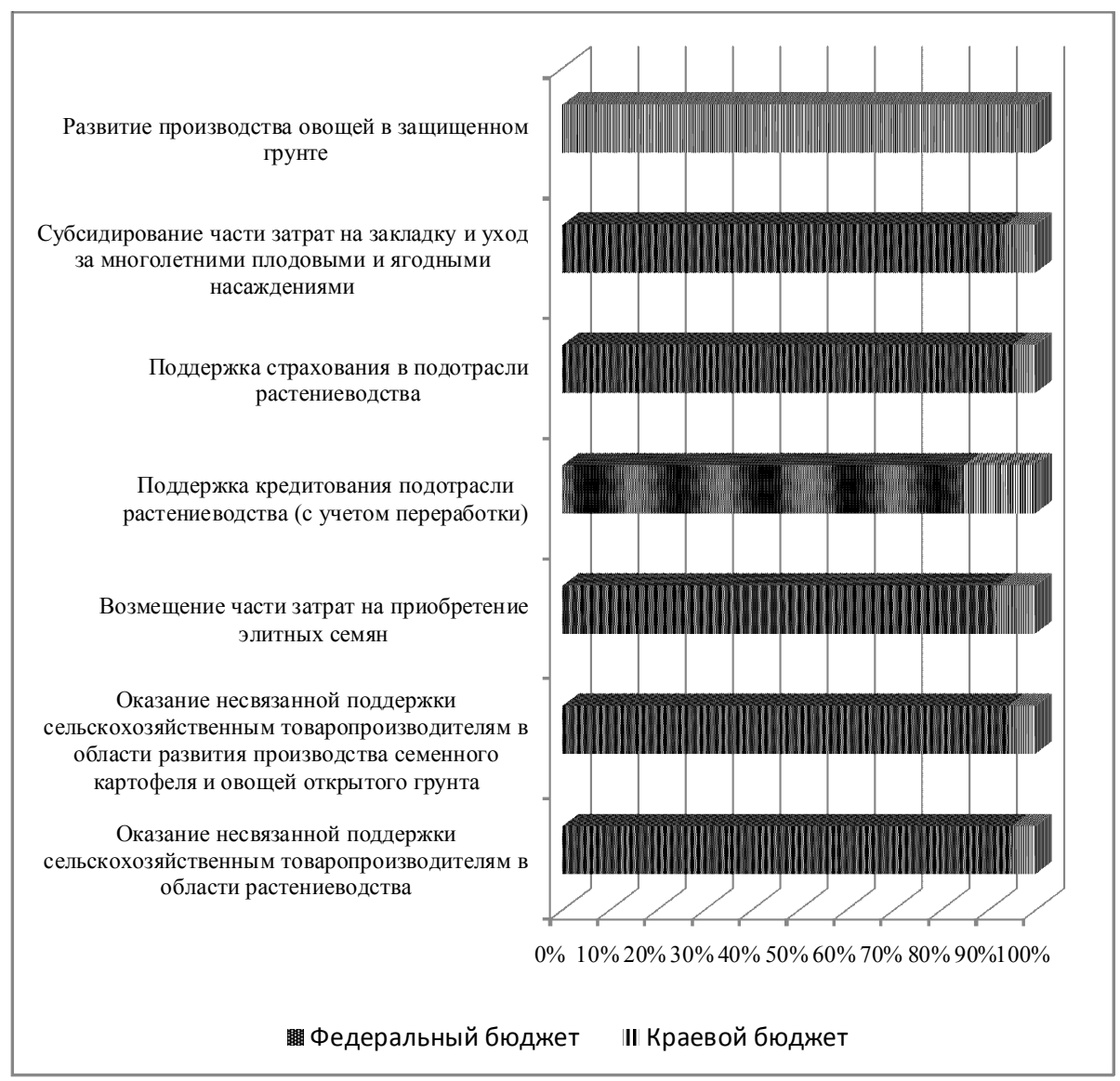

Рис. 5. Структура государственной поддержки в регионе, 2016 г.

Примечание. Составлено автором. 
Такой инструмент государственной поддержки, по нашему мнению, стимулирует развитие сельскохозяйственного страхования и вовлечение в оборот орошаемых земель, увеличение оплаты труда работников, урожайности сельскохозяйственных культур, развитие отрасли животноводства. Применение гидротермического коэффициента при расчете размера субсидии грамотно решает, на наш взгляд, важнейшую экономическую задачу государственной аграрной политики - на уровне отдельного региона выравнивает условия рентабельного ведения аграрного бизнеса для товаропроизводителей, находящихся в разных природноклиматических условиях.

Соотношение доли площадей и субсидий по гидротермическому коэффициенту, а также распределение муниципальных районов Алтайского края по величине гидротермического коэффициента представлены в таблице 1 и на рисунке 6 соответственно [6, с. 16].

Соотношение доли площадей и субсидий по гидротермическому коэффициенту, а также распределение муниципальных районов Алтайского края по величине гидротермического коэффициента представлены в таблице 2 и на рисунке 6 соответственно.

Более $69 \%$ несвязанной поддержки было направлено в районы с гидротермическим коэффициентом в диапазоне от 0,6 до 0,8 , то есть территории, наиболее подверженные засухе.
В расчете на 1 га посевной площади уровень государственной поддержки в регионе значительно ниже, чем в среднем по России и Сибирскому федеральному округу (см. рис. 7).

Целесообразно, на наш взгляд, дать оценку уровня развития сельскохозяйственного производства региона с учетом действующих инструментов ресурсной поддержки.

Исследования показали, что за последние годы в регионе значительно увеличился объем господдержки сельскохозяйственных товаропроизводителей. Наибольший объем господдержки с 2009 г. был выделен в 2015 г. и составил более 5,8 млрд рублей. Позитивным показателем результативности государственной поддержки является тот факт, что в динамике лет в регионе увеличивается производство сельскохозяйственной продукции, а также налоговые поступления. Так, производство продукции сельского хозяйства в регионе в 2016 г. достигло значения в денежном эквиваленте 163 438,3 млн руб., что выше уровня 2009 и 2015 гг. на 213,5 и $115,0 \%$ соответственно (см. табл. 3 ).

Для развития сельскохозяйственного производства и сельских территорий Алтайского края выделяются значительные финансовые ресурсы и используются различные инструменты поддержки, в том числе выравнивающие объективно неравные условия хозяйствования субъектов агробизнеса, тем самым регулирующие рентабельность сельскохозяйственного производства по природно-климатическим зонам региона.

Таблииа 1

\section{Ставки субсидий на оказание несвязанной поддержки сельскохозяйственным товаропроизводителям в области растениеводства в зависимости от гидротермического коэффициента}

\begin{tabular}{|c|c|c|}
\hline \multirow[b]{2}{*}{$\begin{array}{c}\text { Гидротермический } \\
\text { коэффициент }\end{array}$} & \multicolumn{2}{|c|}{ Ставки субсидий на 1 га посевной площади сельскохозяйственных культур, руб. } \\
\hline & $\begin{array}{c}\text { Сельскохозяйственные культуры (за исключением } \\
\text { культур, посеянных сельскохозяйственными то- } \\
\text { варопроизводителями, заключившими в текущем } \\
\text { году договоры страхования урожая данных куль- } \\
\text { тур и имеющими на начало текущего года пого- } \\
\text { ловье коров молочного направления продуктив- } \\
\text { ности не менее } 300 \text { голов или мясного направле- } \\
\text { ния продуктивности не менее } 200 \text { голов) }\end{array}$ & $\begin{array}{c}\text { Культуры, посеянные сельскохозяйственными } \\
\text { товаропроизводителями, заключившими в теку- } \\
\text { щем году договоры страхования урожая данных } \\
\text { культур и имеющими на начало текущего года } \\
\text { поголовье коров молочного направления продук- } \\
\text { тивности не менее } 300 \text { голов или мясного направ- } \\
\text { ления продуктивности не менее } 200 \text { голов }\end{array}$ \\
\hline 0,6 & 130 & 169 \\
\hline 0,7 & 115 & 155 \\
\hline 0,8 & 102 & 144 \\
\hline 0,9 & 90 & 132 \\
\hline 1,0 & 82 & 123 \\
\hline 1,1 & 74 & 116 \\
\hline 1,2 и более & 67 & 112 \\
\hline
\end{tabular}

Примечание. Составлено автором по: [6]. 
Ю.А. Бугай. Экономический анализ эффективности инструментов государственной поддержки

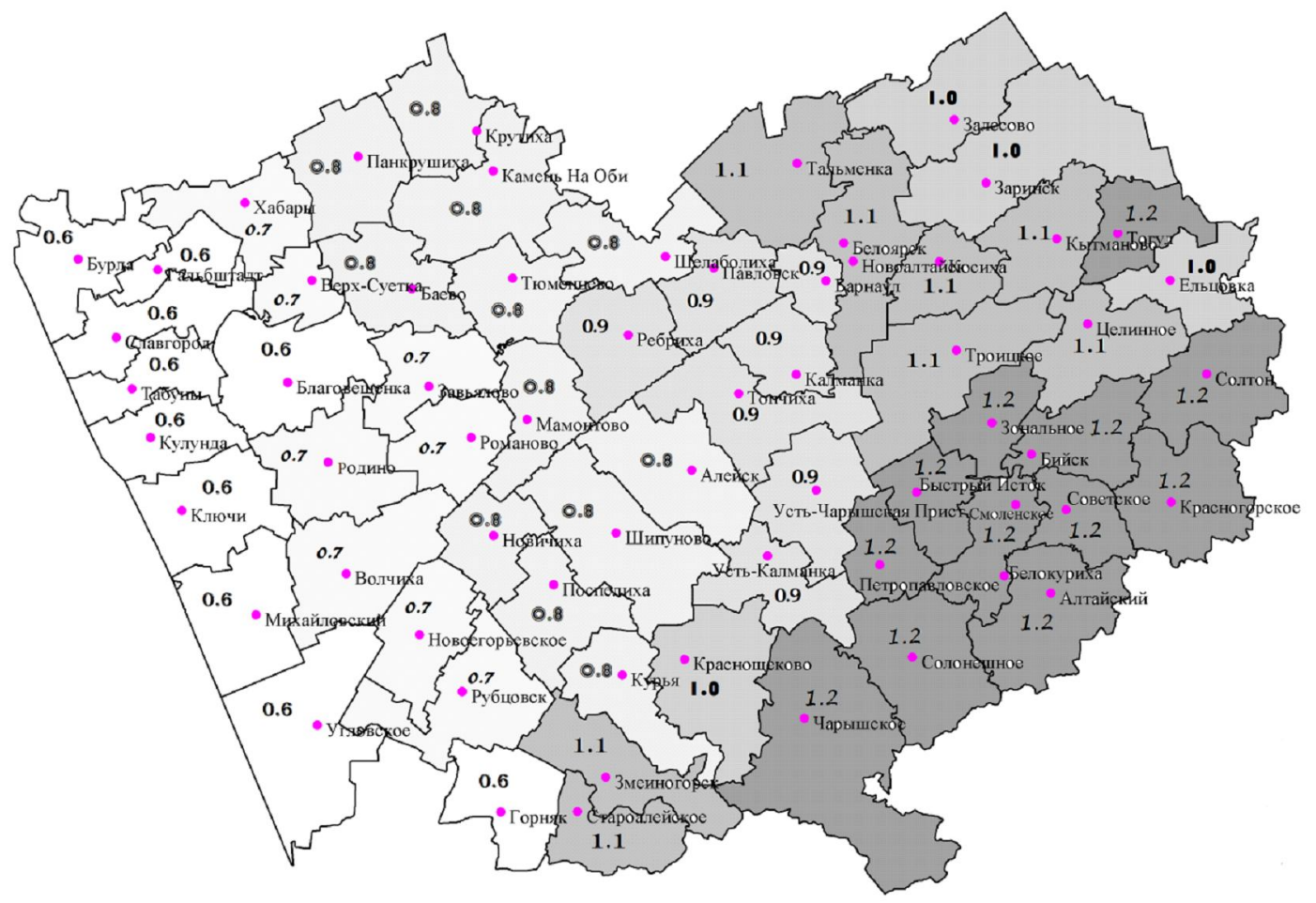

Рис. 6. Распределение муниципальных районов Алтайского края по величине гидротермического коэффициента Примечание. Составлено автором.

\section{Соотношение доли площадей и субсидий по гидротермическому коэффициенту (ГТК)}

\begin{tabular}{|l|r|r|c|r|}
\hline & $\begin{array}{c}\text { Субсидируемая } \\
\text { площадь, га }\end{array}$ & \% к итогу & $\begin{array}{c}\text { Перечислено } \\
\text { субсидий, тыс. руб. }\end{array}$ & \% к итогу \\
\hline ГТК 0,6 & 1038230,80 & 20,60 & 390810,8 & 27,27 \\
\hline ГТК 0,7 & 897287,10 & 17,81 & 284754,1 & 19,87 \\
\hline ГТК 0,8 & 1213024,00 & 24,07 & 325102,6 & 22,68 \\
\hline ГТК 0,9 & 538816,40 & 10,69 & 127532,5 & 8,90 \\
\hline ГТК 1,0 & 185652,00 & 3,68 & 44556,5 & 3,11 \\
\hline ГТК 1,1 & 592864,70 & 11,76 & 135937,9 & 9,48 \\
\hline ГТК 1,2 и более & 573482,10 & 11,38 & 124657,8 & 8,70 \\
\hline & 5039357,1 & 100,00 & 1433352,2 & 100,00 \\
\hline
\end{tabular}

Примечание. Составлено автором.

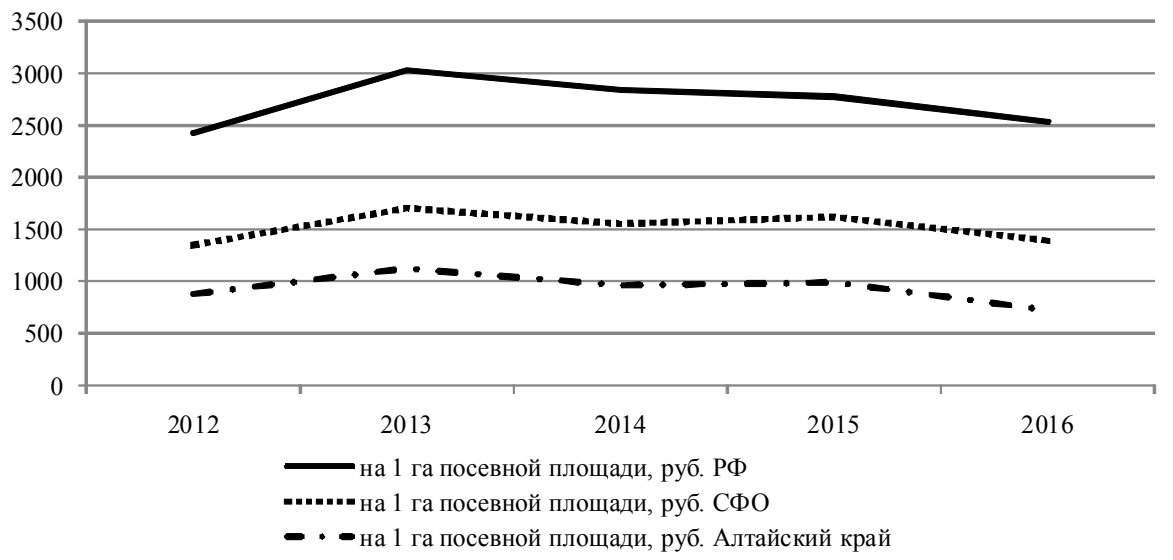

Рис. 7. Сопоставление размера государственной поддержки сельскохозяйственного производства Алтайского края с регионами Российской Федерации

Примечание. Составлено автором. 


\section{Показатели результативности государственной поддержки сельскохозяйственных товаропроизводителей Алтайского края}

\begin{tabular}{|c|c|c|c|c|c|c|c|c|}
\hline Показатели & 2009 г. & 2011 г. & 2012 г. & 2013 г. & 2014 г. & 2015 г. & 2016 г. & $\begin{array}{c}2016 \text { г. } \\
\text { В \% к } \\
2009 \text { г. }\end{array}$ \\
\hline $\begin{array}{l}\text { Господдержка сельского хозяйства с } \\
\text { учетом компенсации ущерба, при- } \\
\text { чиненного в результате ЧС (без } \\
\text { ФЦП «Социальное развитие села до } \\
2013 \text { г.», ФЦП «Устойчивое разви- } \\
\text { тие сельских территорий на } 2014- \\
2017 \text { гг. и на период до } 2020 \text { г.»), } \\
\text { млн руб. }\end{array}$ & 3612,4 & 4625,8 & 4312,5 & 5701,7 & 4147,9 & 5810,2 & 3702,8 & 102,5 \\
\hline В том числе на 1 га пашни, руб. & 554,2 & 711,1 & 662,8 & 875,2 & 636,7 & 889,1 & 565,1 & 102,0 \\
\hline Уплачено налогов, млн руб. & 2967,6 & 4473 & 4324,5 & 5174,5 & 5186,1 & 6164,9 & 6168,1 & 207,8 \\
\hline $\begin{array}{l}\text { В том числе: } \\
\text { на } 1 \text { рубль господдержки, руб. }\end{array}$ & 0,82 & 0,97 & 1,00 & 0,91 & 1,25 & 1,06 & 1,67 & 203,7 \\
\hline на 1 га пашни, руб. & 455,2 & 687,6 & 664,6 & 794,3 & 796,1 & 943,4 & 941,4 & 206,8 \\
\hline $\begin{array}{l}\text { Продукция сельского хозяйства - } \\
\text { всего, млн руб. }\end{array}$ & 76425,4 & 93784 & 94297,4 & 114743 & 113938 & 141356 & 163438,3 & 213,9 \\
\hline $\begin{array}{l}\text { В том числе: } \\
\text { на душу населения, тыс. руб. }\end{array}$ & 31,4 & 38,9 & 39,2 & 47,9 & 47,7 & 59,4 & 68,9 & 219,4 \\
\hline на 1 га пашни, тыс. руб. & 11,7 & 14,4 & 14,5 & 17,6 & 17,5 & 21,6 & 24,9 & 212,8 \\
\hline на 1 руб. господдержки, руб. & 21,2 & 20,3 & 21,9 & 20,1 & 27,5 & 24,3 & 44,1 & 208,0 \\
\hline
\end{tabular}

Примечание. Составлено автором по: [6].

Вместе с тем считаем, что в целях совершенствования механизма погектарной поддержки необходимо учитывать нормативные затраты на производство и реализацию сельскохозяйственной продукции с учетом рекомендуемых норм ведения отрасли. Одним из инструментов такой поддержки должна стать цена на основные виды сельскохозяйственной продукции, которая обеспечит доходность производства его производителям. Способствовать стабильному получению дохода производителями, на наш взгляд, можно путем ежегодного определения объема государственной ресурсной поддержки производителей, исходя из сопоставления базовой и рыночной цен. Базовая цена должна стать инструментом индикативного планирования, а ее расчет должен лечь в основу определения объема государственной ресурсной поддержки производителей. Такая форма государственной поддержки предполагает, что производитель должен соблюдать научно-обоснованные технологии производства (повышать плодородие почв, выполнять рекомендуемые агротехнические работы, использовать новые технологии и т. д.). В противном случае производители не могут претендовать на получение ресурсной поддержки со стороны государства.
С учетом ограниченности федерального и регионального бюджетов такая форма государственной ресурсной поддержки не предполагает только прямые денежные выплаты. Она может быть представлена в различных формах [2, с. 1316-1317].

Для реализации данного мероприятия необходимо проводить:

- мониторинг динамики рыночных цен на сельскохозяйственную продукцию, а также средств производства, используемых в сельском хозяйстве, для установления предельных размеров их соотношения;

- анализ издержек производства сельскохозяйственной продукции, учитывающий научно обоснованное и эффективное ведение производства по природно-климатическим зонам;

- организацию государственных интервенций на сельскохозяйственном рынке, обеспечивающих закуп сельскохозяйственной продукции по гарантированным ценам, квотирование объемов закупки.

Механизм региональной государственной поддержки, на наш взгляд, решает не только экономические задачи региона и государства, но и социально-политические, а именно обеспечение: - продовольственной безопасности; 
Ю.А. Бугай. Экономический анализ эффективности инструментов государственной поддержки

- сельской занятости населения;

- повышения благосостояния работников, занятых сельскохозяйственным производством; риторий.

- контроля за развитием сельских тер-

\section{ПРИМЕЧАНИЕ}

${ }^{1}$ Исследование подготовлено в рамках поддержанного РФФИ научного проекта № 16-12-22018.

\section{СПИСОК ЛИТЕРАТУРЫ}

1. Бугай, Ю. А. Анализ стратегий воздействия государства на развитие экономики / Ю. А. Бугай, С. А. Кореннов // Вестник Алтайского государственного аграрного университета. - 2016. - № 8 (142). C. 174-177.

2. Бугай, Ю. А. Систематизация информационного обеспечения устойчивого развития продовольственного рынка / Ю. А. Бугай, А. В. Боговиз // Политематический сетевой электронный научный журнал Кубанского ГАУ.-2013.-№93 (09). -С. 1302-1317.

3. Доклад о ходе и результатах реализации в 2016 году государственных и ведомственных целевых программ в сфере развития сельского хозяйства Алтайского края / Министерство сельского хозяйства Алтайского края. - Барнаул, 2017.

4. Лужков, Ю. М. Сельский капитализм в России: столкновение с будущим / Ю. М. Лужков. M., 2005.

5. Лукьянов, А. Н. Импортозамещение в АПК региона: проблемы и методология их решения / А. Н. Лукьянов, Ю. А. Бугай, Г. М. Гриценко // АПК: экономика, управление. - 2016. - № 8. - С. 64-71.

6. Постановление Правительства Алтайского края от 09.02.2017 № 34 «Об утверждении порядка предоставления из краевого бюджета субсидий на оказание несвязанной поддержки в области растениеводства». - Доступ из справ.-правовой системы «КонсультантПлюс».

\section{REFERENCES}

1. Bugay Yu.A., Korennov S.A. Analiz strategiy vozdeystviya gosudarstva na razvitie ekonomiki [Analysis of the Strategies of State Influence on Economy Development]. Vestnik Altayskogo gosudarstvennogo agrarnogo universiteta, 2016, no. 8, pp. 174-177.

2. Bugay Yu.A., Bogoviz A.V. Sistematizatsiya informatsionnogo obespecheniya ustoychivogo razvitiya prodovolstvennogo rynka [Systemization of Information Support for Sustainable Development of the Food Market]. Politematicheskiy setevoy elektronnyy nauchnyy zhurnal Kubanskogo GAU, 2013, no. 93 (09), pp. 1302-1317.

3. Doklad o khode i rezultatakh realizatsii v 2016 godu gosudarstvennykh i vedomstvennykh tselevykh programm $\mathrm{v}$ sfere razvitiya selskogo khozyaystva Altayskogo kraya [A Report on the Progress and Results of the Implementation in 2016 of the State and Departmental Target Programs in the Sphere of Agriculture Development in the Altai Region]. Ministerstvo selskogo khozyaystva Altayskogo kraya [Ministry of Agriculture of the Altai Region]. Barnaul, 2017.

4. Luzhkov Yu.M. Selskiy kapitalizm v Rossii: stolknovenie s budushchim [Rural Capitalism in Russia: Facing the Future]. Moscow, 2005.

5. Lukyanov A.N., Bugay Yu.A., Gritsenko G.M. Importozameshchenie $\mathrm{v}$ APK regiona: problemy i metodologiya ikh resheniya [Import Substitution in the Agro-Industrial Complex of the Region: Problems and Methodology of Their Solutions]. APK: ekonomika, upravlenie, 2016, no. 8, pp. 64-71.

6. Postanovlenie Pravitelstva Altayskogo kraya ot 09.02.2017 № 34 «Ob utverzhdenii poryadka predostavleniya iz kraevogo byudzheta subsidiy na okazanie nesvyazannoy podderzhki $v$ oblasti rastenievodstva» [Resolution of the Government of the Altai Region of February 9, 2017 no. 34 "On Approval of Procedure of Granting Finance from the Regional Budget for Indirect Support in the Field of Agriculture"]. Access from Reference Legal System «KonsultantPlyus».

\section{Information about the Author}

Yuriy A. Bugay, Candidate of Sciences (Economics), Associate Professor, Department of Production Management and Agrobusiness, Altai State Agricultural University, Prosp. Krasnoarmeyskiy, 98, 656049 Barnaul, Russian Federation, yrbugai@mail.ru.

\section{Информация об авторе}

Юрий Александрович Бугай, кандидат экономических наук, доцент кафедры управления производством и агробизнеса, Алтайский государственный аграрный университет, просп. Красноармейский, 98, 656049 г. Барнаул, Российская Федерация, yrbugai@mail.ru. 